УДК 637.02

DOI https://doi.org/10.15673/swonaft.v84i1.1867

\title{
МАТЕМАТИЧНЕ МОДЕЛЮВАННЯ ДІї ТЕПЛОВОГО ВИПРОМІНЮВАННЯ НА ТЕРМІЧНУ ОБРОБКУ КОВБАСНИХ БАТОНІВ
}

\author{
Ошипок І. М., д-р техн. наук, професор \\ Львівський торговельно-економічний університет, м. Львів
}

\begin{abstract}
Анотація. У статті досліджено використання теплоти інфрачервоного випромінювання яке є одним з ефективних иляхів інтенсифікації теплової обробки ковбасних батонів і дозволяє значно скоротити тривалість ї̈ обробки і підвищити якість готових виробів. На основі сучасного підходу вирімене завдання пов'язане з тепловою обробкою, яке полягає в дослідженні тих способів і режимів, забезпечуючих необхідну інактивачію мікрофлори, максимальне збереження харчової иінності продукту. На основі визначених передумов розглянута математична модель спільного тепломасопереносу і теплової обробки ковбасних батонів циліндричної форми в обсмажувальній установці з інфрачервоним (IЧ) -нагріванням. Досліджені такі способи і режими, які забезпечували б, разом з необхідною інактивацією шкідливої мікрофлори, максимальне збереження харчової иінності продукту. Досліджено комплекс параметрів, які мають безпосередній вплив на хід процесу теплової дії на ковбасні батони. Враховане загасання променистого потоку, щзо проникає в продукт, яке описане параболічним законом. Реалізовані ефективні шляхи інтенсифікації теплової обробки ковбасних батонів з використання енергії і підвищення якості готових виробів на основі математичної моделі дї̈ теплового електромагнітного поля IЧ діапазону. Поставлена і аналітично вирішена задача спільного тепло- $i$ масопереносу при інфрачервоному нагріванні ковбасного батона циліндричної форми. Отримані результати дозволять розрахувати поля температури і вмісту вологи, усереднені значення відповідних потенціалів перенесення, температури нагрівання, витрати тепла в прочесі теплообміну, а також одержати формули, зручні для інженерних розрахунків. Запропоновані аналітичні конструкиії дають можливість визначати час, необхідний для досягнення продуктом певної температури $і$ вмісту вологи, забезпечуючи втрати маси при підсушуванні в діапазоні 0,5-1,8 \% при тривалості процесу від 3 до 30 хвилин.
\end{abstract}

Ключові слова: модель, тепломасоперенос, ковбасні, вироби, ІЧ-нагрівання

\section{MATHEMATICAL SIMULATION OF THERMAL ACTION RADIATION FOR HEAT TREATMENT SAUSAGE BARS}

\author{
Oshchypok I.M., Dr. Sciences, Professor \\ Lviv trade and economic University, Lviv
}

\begin{abstract}
The article examines the use of heat of infrared radiation, which is one of the effective ways to intensify the heat treatment of sausage loaves and can significantly reduce the duration of its processing and improve the quality of finished products. On the basis of the modern approach the solved problem is connected with thermal treatment which consists in research of those ways and the modes providing necessary inactivation of microflora, the maximum preservation of nutritional value of a product. Based on certain prerequisites, a mathematical model of joint heat and mass transfer and heat treatment of cylindrical sausage loaves in a frying unit with infrared (IR) heating is considered. The following methods and regimes have been studied, which would ensure, together with the necessary inactivation of harmful microflora, the maximum preservation of the nutritional value of the product. A set of parameters that have a direct impact on the course of the thermal action on sausage loaves has been studied. The attenuation of the radiant flux entering the product, which is described by the parabolic law, is taken into account. Implemented effective ways to intensify the heat treatment of sausage loaves using energy and improve the quality of finished products based on a mathematical model of the thermal electromagnetic field of the IR range. The problem of joint heat and mass transfer during infrared heating of a cylindrical sausage loaf is set and analytically solved. The obtained results will allow to calculate the fields of temperature and moisture content, the average values of the corresponding transfer potentials, heating temperature, heat consumption in the heat exchange pro-
\end{abstract}


cess, as well as to obtain formulas convenient for engineering calculations. The proposed analytical constructions make it possible to determine the time required for the product to reach a certain temperature and moisture content, providing weight loss during drying in the range of 0.5-1.8\% with a duration of the process from 3 to 30 minutes.

Keywords: model, warm mass transfer, sausages, products, infrared heating

Постановка проблеми в загальному вигляді та зв'язок із найважливішими науковими чи практичними завданнями. Покращення споживчих властивостей ковбасних виробів на всіх стадіях виробництва i збільшення об'ємів продукції, що переробляється з одиниці сировини, можна досягти в першу чергу оптимальною організацією технологічних схем, структур і систем в цілому з раціональним використанням енергетичних ресурсів і сировини, виробничих потужностей і промислових технологій. Теплова обробка - одна 3 важливих процесів при виробництві ковбасних виробів, оскільки саме цей процес зрештою визначає якість готового продукту, у тому числі такі його показники, як зовнішній вигляд, запах, смак, консистенція, вміст мікроорганізмів тощо. Сучасний підхід до вирішення питань, пов'язаних з тепловою обробкою, полягає в дослідженні таких способів і режимів, які забезпечували б разом з необхідною інактивацією мікрофлори максимальне збереження харчової цінності продукту.

Розробка практичних рекомендацій щодо ефективної реалізації вже існуючих способів ІЧ-обробки виробів та/або пошуку нових, визначення оптимальних вимог до технічних характеристик ІЧ-апаратів проходить через виявлення взаємозв'язку стану початкової сировини і параметрів технологічного обладнання. Цей зв'язок настільки значний, що в деяких технологічних дослідженнях контрольовані показники і закономірності змін, які встановлюються, є характеристиками властивостей не власне обробки, а оброблюваного продукту, технологічних характеристик обладнання і готової продукції. У цих випадках ми володіємо лише опосередкованими (побічними) результатами закономірностей процесу, на якому лежить набір конкретних (специфічних) умов і які важко відтворити за інших умов. ІЧ термообробка має ряд переваг: короткий період обробки, покращені санітарно-гігієнічні умови виготовлення ковбасних виробів і збереження смакових якостей продукту. В процесі теплової обробки випромінювання проникає в сформовані ковбасні батони рівномірно і створює стабільний тепловий вплив на формування готової продукції. При підсушуванні 3 поверхні ковбасної оболонки видаляється волога, що сприяє рівномірному забарвленню поверхні, i прониканні в ковбасний батон коптильних речовин при подальшому обсмажуванні. Підсушування вважається закінченим, якщо температура поверхні продукту досягне $50{ }^{\circ} \mathrm{C}$, тому ії тривалість для конкретного виду ковбас залежить від діаметра ковбасного батона. Втрати маси при підсушуванні можуть складати 0,5-1,8 \% при тривалості процесу від 3 до 30 хв.

Аналіз останніх досліджень і публікацій При підсушуванні з поверхні ковбасного батону видаляється волога змочування (механічно утримувана вода), що сприяє дифузії в продукт коптильних речовин при подальшому обсмажуванні.

У науковій літературі приділяється значна увага проблемам теплового оброблення варених ковбасних виробів у термокамерах. Значний вклад у розвиток цих досліджень внесли Гінзбург А.С., Рогов I.А., Некрутман С.В., Ільясов С.Г., Красніков В.В. Питання аналітичного розв'язку задачі спільного тепломасопереносу при інфрачервоному нагріванні ковбасних виробів досліджували Воронєнко Б.А., Пєлєнко В.В., Старікова В.В. Сильні наукові школи, які займаються цією проблематикою, працюють у Національному університеті харчових технологій, Одеській національній академії харчових технологій. Проведені дослідження мають виразне технологічне спрямування. Так, у праці О.О. Нескуба [2] наведені результати досліджень впливу технологічних режимів на вихід готового продукту — ковбаси вареної «Лікарська» — та запропоновано нову технологію іiі виробництва, в якій, порівняно з традиційною, додана стадія сушіння для забезпечення рівномірного прогрівання ковбасного батона. При цьому автор наводить дані про покращення органолептичних показників і поліпшення санітарного стану виробів. Загальні втрати маси були в центрі уваги і роботи А.Д. Солецької [4]. Як керовані параметри розглянуто вплив співвідношення температур обжарювання i варіння, підвищення яких призводить до збільшення втрат маси продукту. Дослідження, виконані під керівництвом В.І. Павелка у НУХТ [3], були спрямовані на скорочення тривалості теплового оброблення варених ковбас різних геометричних розмірів у термокамерах. Розроблений алгоритм теплового розрахунку установки для термічного оброблення варених ковбас, в якому використано аналітичні залежності та емпіричні співвідношення.

Постановка завдання. На основі розглянутої математичної моделі дії теплового випромінювання, на термічну обробку ковбасних батонів, реалізувати ефективні шляхи інтенсифікації теплової обробки 3 використання енергї̈ електромагнітного поля інфрачервоного діапазону для підвищення якості готових виробів.

Виклад основного матеріалу дослідження. При складанні математичної моделі процесу термічної обробки ковбасних виробів в термоустановках з ІЧ-нагріванням конвективним теплообміном від навколишнього середовища нехтуємо, причому, чим вище температура джерела теплового випромінювання, тим більш обгрунтованими ця передумова $[1,5]$.

$$
\text { Наукові праці, Том 84, випуск } 1
$$


Променевий потік, проникаючи в продукт, загасає за експоненціальним законом [6]. При товщині продукту s > 10 мм і високому значенні коефіцієнта поглинання він швидко згасає під час проникнення в продукт [7], тому можна вважати, що вся енергія віддається поверхні, а в нагріванні внутрішніх шарів участі не бере.

В цьому випадку, особливо для періоду постійної швидкості сушіння - стадії підсушування (від початку процесу до часу $\tau_{1}$ ), загасання променистого потоку, що проникає в продукт, може бути описано параболічним законом [6]:

$$
\begin{gathered}
w(r)=w_{0} \frac{r^{2}-\lambda_{n p}^{2}}{R^{2}-\lambda_{n p}^{2}} \\
0<\lambda_{n p} \leq r \leq R
\end{gathered}
$$

де $w$ - проникаюча потужність ІЧ випромінювання, Вт/м³;

$w_{0}$ - потужність ІЧ-джерела теплоти, Вт/м³

$r$ - поточна координата, м;

$R$ - радіус поперечного січення циліндра ковбасного батону, м;

$\lambda_{n p}$ - гранична глибина проникнення інфрачервоного випромінювання в ковбасний батон.

Приймаємо ковбасний батон за тіло основної геометричної форми - нескінчений циліндр, однорідний і ізотропний, теплофізичні характеристики якого в процесі термообробки залишаються незмінними. При ІЧ-випромінюванні нагрівання відбувається 3 поверхні, а внутрішнім шарам ковбасного батону теплота передається теплопровідністю і вологопровідністю. Для спрощення аналітичних досліджень не будемо враховувати процес термодифузії вологи, тобто зміни вмісту вологи за рахунок термовологопровідності, 3 урахуванням порівняно повільної ії зміни з часом при ІЧ-нагріванні [7].

Відповідно до зазначених припущень нагрівання ковбасного батона в коптильній установці 3 ІЧнагріванням може бути описане наступною крайовою задачею пов'язаною з тепло- і масопереносом: потрібно вирішити систему диференціальних рівнянь в часткових похідних в циліндричних координатах

$$
\begin{gathered}
\frac{\partial t}{\partial \tau}=a_{q}\left(\frac{\partial^{2} t}{\partial r^{2}}+\frac{1}{r} \frac{\partial t}{\partial r}\right)+\frac{\varepsilon \rho}{c_{q}} \frac{\partial u}{\partial t}+\frac{w(r)}{c_{q} \gamma_{0}} \\
\frac{\partial u}{\partial \tau}=\left(\frac{\partial^{2} u}{\partial r^{2}}+\frac{1}{r} \frac{\partial u}{\partial r}\right)
\end{gathered}
$$

де $t(r, \tau)$ - температура, $\mathrm{K},{ }^{\circ} \mathrm{C}$;

$a_{q}$ - коефіцієнт температуропровідності;

$\varepsilon$ - коефіцієнт масового переходу $(0<\varepsilon<1)$;

$\rho$ - питома теплота фазового переходу, Дж/кг;

$u(r, \tau)$ - вологовміст, кг вологи на кг абсолютно сухої речовини;

$c_{q}$ - питома теплоємність, Дж/кгК;

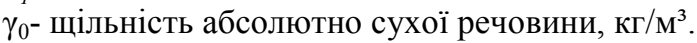

За таких умов розглянемо зміст розглядуваних рівнянь.

Рівняння (2) описує теплоперенос з внутрішнім джерелом тепла, що визначається залежністю (1);

$$
\left(0<\tau<\tau_{1} ; 0<r<R\right)
$$

де $\tau_{1}$ - час закінчення першого періоду термічної обробки- підсушування, c;

Рівняння (3) описує вологоперенос;

$$
\begin{gathered}
t(r, 0)=t_{0}=\text { const } \\
u(r, 0)=u_{0}=\text { const }
\end{gathered}
$$

Рівняння (4) і (5) - початкові умови, що задають рівномірний розподіл температури і вмісту вологи в ковбасному батоні в момент початку процесу нагрівання;

$$
\begin{aligned}
& \frac{\partial(0, \tau)}{\partial}=\frac{\partial u(0, \tau)}{\partial}=0 \\
& t(0, \tau)<\infty, u(0, \tau)<\infty)
\end{aligned}
$$

Рівняння (6) і (7) - умови симетрії і фізичної обмеженості температури і вмісту вологи; 


$$
-\lambda_{q} \frac{\partial t(R, \tau)}{\partial r}+q(\tau)-(1-\varepsilon) q_{m}(\tau)=0
$$

де $\lambda_{q}$-коефіцієнт теплопровідності, Вт/(мК);

$q(\tau)=k_{1} c_{q} \gamma_{0} R \Delta t e^{-k_{1} r}+R k_{2} \rho \gamma_{0} u_{0} e^{k_{2} \tau}$ - експериментально знайдена щільність теплового потоку на поверхні тіла, $\mathrm{BT} / \mathrm{M}^{2}$;

$q_{m}(\tau)=k_{2} \gamma_{0} u_{0} \mathrm{Re}^{-k_{2} r}$ - експериментально встановлена щільність потоку маси речовини через поверхню тіла, кг/( $\left.\mathrm{M}^{2} \mathrm{c}\right)$; $1 / \mathrm{c}$

$k_{l^{-}}$коефіцієнт, що характеризує спадання температури поверхні тіла за експоненціальним законом,

$k_{2}$ - коефіцієнт сушіння, $1 / \mathrm{c}$;

$u_{0}-$ початковий вологовміст;

$\tau-$ час, c;

$\Delta t=t_{\text {мс }}-t_{0}$ - різниця температур, $\mathrm{K},{ }^{\circ} \mathrm{C}$;

$t_{0}$ - початкова температура;

$t_{\text {мc }}$-максимальна температура середовища в камері;

Рівняння (8) - гранична умова другого роду, що задає потік теплоти через поверхню тіла;

$$
a_{m} \gamma_{0} \frac{\partial u(R, \tau)}{\partial r}+q_{m}(\tau)=0
$$

де $a_{m}$ - коефіцієнт потенціало - (волого) провідності, $\mathrm{M}^{2} / \mathrm{c}$.

Рівняння (9) - гранична умова другого роду, що описує вологообмін тіла з навколишнім середовищем. Математична модель описана рівняннями (2-9) розв'язується методом інтегрального перетворення Лапласа в наступному безрозмірному вигляді:

$$
\begin{aligned}
& T\left(X, F_{0}\right)=\frac{t(r, \tau)-t_{0}}{t_{\mu c}-t_{0}}=2\left\{1+\frac{P_{0}}{2\left(1-X_{n p}^{2}\right)}\left[\frac{13}{768}-\left(X_{n p}^{2}-\frac{1}{8}\right) F_{0}-\frac{1}{16} X^{4}+\frac{1}{32} X^{2}-\sum_{n=1}^{\infty} \frac{2 J_{0}\left(\mu_{n} X\right)}{\mu_{n}^{4} J_{0}\left(\mu_{n}\right)} e^{-\mu_{n}^{2 F_{0}}}\right]\right. \\
& +\frac{\varepsilon K_{0} L u}{2\left(1-L_{u}\right)}\left[\frac{\sqrt{P d^{2}} J_{0}\left(\sqrt{P d_{2}} X\right)}{J_{1} \sqrt{P d_{2}}}-\frac{\sqrt{\frac{P d_{2}}{L u}} j_{0}\left(\sqrt{\frac{P d_{2}}{L u}} j_{0}\left(\sqrt{\frac{P d_{2}}{L u} X}\right)\right)}{j_{1}\left(\sqrt{\frac{P d_{2}}{L u}}\right)}\right] e^{-P d_{2} F_{0}}-\frac{\sqrt{P d_{1}} J_{0}\left(\sqrt{P d_{1}} X\right)}{2 J_{1} \sqrt{P d_{1}}} e^{-P d_{2} F_{0}}+
\end{aligned}
$$

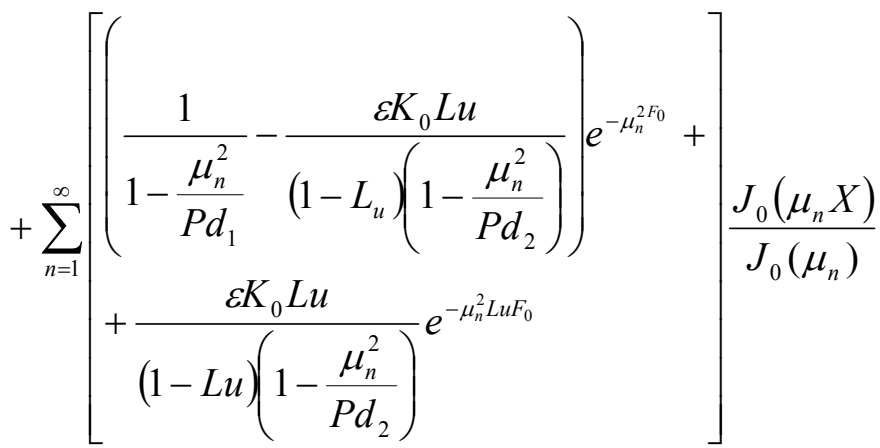

де $\mathrm{T}\left(\mathrm{X}, \mathrm{F}_{0}\right)=\left(t(x, \tau)-t_{0}\right) /\left(t_{m}-t_{0}\right)$ безрозмірна температура;

$\theta\left(X, F_{0}\right)=\left(u_{0}-u(r, \tau)\right) / u_{0}$ безрозмірний вологовміст;

$X=r / R$ - безрозмірна координата;

$F_{0}=a_{q} \tau /{ }_{R^{2}}$ - критерій гомохронності (число Фур'є);

но;

$J_{0}(z), J_{l}(z)$ - функції Бесселя від дійсного аргументу z нульового порядку і першого роду відповід-

$$
P d_{1}=k_{1} R^{2} / a_{q}, P d_{1}=k_{2} R^{2} / a_{q} \text { - числа Прєдводітєлєва (теплообмінне та масообмінне) }
$$




$$
\begin{gathered}
L u=a_{m} / a_{q} \text { - критерій (Число Ликова) взаємозв'язку масо-і теплопереносу; } \\
K_{0}=r \Delta u /\left(c_{q} \Delta t\right) \text { - число Косовіча; } \\
\text { для } L u=1\left(a_{m}=a_{q}\right) \\
T(X, F o)=\frac{t(r, \tau)-t_{0}}{t_{v c}-t_{0}}=2\left\{1+\frac{P_{0}}{2\left(1-X_{n p}^{2}\right)}\left[\frac{13}{768}-\left(X_{n p}^{2}-\frac{1}{8}\right) F_{0}-\frac{1}{16} X^{4}+\frac{1}{32} X^{2}-\sum_{n=1}^{\infty} \frac{2 J_{0}\left(\mu_{n} X\right)}{\mu_{n}^{4} J_{0}\left(\mu_{n}\right)} e^{\left.-\mu_{n}^{2} F_{0}\right]}\right]-\right. \\
\left.-\frac{\sqrt{P d_{1}} J_{0}\left(\sqrt{P d_{1}} X\right)}{J_{1}\left(P d_{1}\right)} e^{-P d_{1} F_{0}}+\sum_{n=1}^{\infty} \frac{j_{0}\left(\mu_{n} X\right.}{\left(1-\frac{\mu_{n}^{2}}{P d_{1}}\right) J_{0}\left(\mu_{n}\right)} e^{-\mu_{n}^{2} F_{0}}\right\} \\
\theta\left(X, F_{0}\right)=2\left[1-\frac{1}{2} \sqrt{\frac{P d_{2}}{L u}} \frac{j_{0}}{j_{1}\left(\sqrt{\frac{P d_{2}}{L d_{2}}}\right.} e^{-P d_{2} F_{0}}+\sum_{n=1}^{\infty} \frac{j_{0}\left(\mu_{0} X\right)}{\left(1-\frac{\mu_{n}^{2} L u}{P d_{2}}\right) j_{0}\left(\mu_{n}\right)} e^{-\mu_{n}^{2} F_{0}}\right]
\end{gathered}
$$

де $\mu_{n}$ - послідовні позитивні корені рівняння

$$
J_{1}(\mu)=0
$$

Аналіз отриманих розв'язків (1) і (12) показує, що завдяки швидкому збільшенню абсолютної величини послідовного ряду значень характеристичних коренів $\mu_{n}$ рівняння (13), $\mu_{1}<\mu_{2}<\ldots<\mu_{n}<\ldots$, а отже, швидкого зменшення експоненційних співмножників $e^{-\mu_{n}^{2} F_{0}}$ нескінченні суми, що входять до рішення, сходяться досить швидко. Тому, починаючи з певного значення числа Фур'є, з заздалегідь заданим ступенем точності з усього ряду розкладання можна прийняти до уваги один-два перших члени. Таке спрощення має велике практичне значення через істотне скорочення обсягу розрахункової роботи і можливості представлення спільних рішень в зручній для практичного застосування формі.

Так, формулою зручною для інженерних розрахунків полів потенціалу вологопереносу, буде такий вираз, отриманий з (12) при $\mathrm{n}=1$ :

$$
\frac{u(r . \tau)}{u_{0}}=1-2\left[\sqrt{\frac{P d_{2}}{L u}} \frac{\left(\sqrt{\frac{P d_{2}}{L u} X}\right)}{J_{0}\left(\sqrt{\frac{P d_{2}}{L u}}\right)} e^{-P d_{2} F_{0}}+\frac{2 J_{0}\left(\mu_{1} X\right)}{\left(1-\frac{\mu_{1}^{2} L u}{P d_{2}}\right) J_{0}\left(\mu_{1}\right)} e^{-\mu_{1}^{2} F_{0}}\right]
$$

Середнє значення безрозмірною величини потенціалу переносу вологи для спрощеного виразу $\Theta(\mathrm{X}, \mathrm{Fo})$ при $\mathrm{n}=1$

$$
\bar{\theta}\left(F_{0}\right)=\frac{u_{0}-\bar{u}(\tau)}{u_{0}}=2 \int_{0}^{1} X \theta\left(X, F_{0}\right) d x=2\left(1-e^{-P d_{1} F_{0}}\right)
$$

Обмежуючись одним першим членом ряду, отримуємо приблизно формулу для розрахунку часу, необхідного для досягнення тілом яке нагрівається певного вмісту вологи:

$$
\tau=\frac{\bar{\theta}}{2 k_{2}}
$$

Середнє значення безрозмірного потенціалу температури для спрощеного виразу $\mathrm{T}(\mathrm{X}, \mathrm{Fo})$ при $\mathrm{n}=1$

$$
\bar{T}\left(F_{0}\right)=2 \int_{0}^{1} X T\left(X, F_{0}\right) d x=\frac{t(x, \tau)-t_{0}}{t_{M c}-t_{0}}=\frac{P_{0}}{\left(1-X_{n p}\right)^{2}}+2 P d_{1} F_{0}
$$


Для знаходження часу доведення продукту до необхідної середньої об'ємної температури, запишемо вираз в наступному вигляді:

$$
\tau=\frac{1}{2 k_{1}\left(t_{M c}-t_{0}\right)}\left(t-t_{0}-\frac{\omega_{0} R^{2}}{\lambda_{q}\left(1-\frac{\lambda_{n p}^{2}}{R^{2}}\right)}\right)
$$

Висновки. Поставлена і аналітично вирішена задача спільного тепло- і масопереносу при інфрачервоному нагріванні ковбасного батону циліндричної форми. Отримані розв'язки дозволяють розрахувати температурні поля і вміст вологи, визначати усереднені значення відповідних потенціалів перенесення, швидкість нагрівання, витрату тепла в процесі теплообміну. Отримані формули, зручні для інженерних розрахунків. Розроблені аналітичні вирази дають можливість визначити час, необхідний для досягнення певної температури і вмісту вологи продуктом який піддається тепловій обробці.

\section{References}

1. Bondarenko, N.V. (2013). Doslidzhennya rezhymiv teplovoyi obrobky varenykh kovbas u suchasnykh termokame-rakh. Kharchova nauka i tekhnolohiya, 2. 92-94.

2. Neskuba, O.O., Chepelyuk, O. M., Chepelyuk, O. O. (2018). Vyznachennya parametriv teplovoho obroblennya kovbasy varenoyi «Likars'ka» v univer-sal'niy termokameri. Naukovi pratsi NUKHT, 24(2), 146-153

3. Pavelko, V.I., Sokolenko, O.Yu., Zaslavs'kyy, A.I. (2012). Doslidzhennya vplyvu deyakykh tekhnolohichnykh faktoriv na tryvalist' protsesu termichnoyi obrobky kovbasnykh vyrobiv. Naukovi pratsi Natsional'noho universytetu kharchovykh tekhnolohiy, 45, 31-37.

4. Solets'ka, A.D. (2014). Optymizatsiya rezhymiv termichnoho obroblennya varenykh kovbas. Kharchova nauka i tekh-nolohiya, 3, 73-76.

5. Starikov, V.V., Voronenko, B.A. (2007). Primeneniye IK-nagreva pri kopchenii. Mezhvuzovskiy sbornik nauchnykh trudov «Teoriya i praktika razrabotki i ekspluatatsii pishchevogo oborudovaniya», SPb: SPbGUNiPT, 12-17.

6. Bakalis, S., Cox, P.W., Fryer, P.J. (2001). Modelling thermal processes: heating. Food Process Modelling, 340364.

7. Tornberg, E. (2005). Effects of heat on meat proteins - Implications on structure and quality of meat products. Meat Science, 70( 3), 493-508. 